\title{
Effect of anti-inflammatory agents on the haemorrhagic response of mouse skin to Bordetella pertussis heat-labile toxin
}

\author{
R. PARTON
}

Department of Microbiology, University of Glasgow, Alexander Stone Building, Garscube Estate, Bearsden, Glasgow $\mathrm{G61} 1 \mathrm{OH}$

\begin{abstract}
Summary. Bordetella pertussis heat-labile toxin (HLT) was assayed by the haemorrhagic response produced by subcutaneous injection into weaned mice. Young mice, 3-5 weeks old of either sex, were highly responsive but they became resistant to HLT as they matured. Two anti-inflammatory agents, prednisolone and meclofenamate, inhibited the skin reactions in young mice. When given intraperitoneally, prednisolone was most inhibitory if it was injected just before, or at the same time as, HLT challenge. Prednisolone given $3 \mathrm{~h}$ after challenge, when the skin reactions had started to develop, did not significantly attentuate the final response. Both drugs were even more effective when mixed with the HLT challenge and injected subcutaneously. These findings are discussed in relation to the possible mechanism of action of HLT and to the reported beneficial effects of corticosteroids in the treatment of whooping cough.
\end{abstract}

\section{Introduction}

A major toxic component of Bordetella pertussis is the dermonecrotising heat-labile toxin (HLT). The mechanism of action of HLT is unknown but it is lethal when given intraperitoneally (ip) or intravenously to mice, guinea pigs or rabbits. When injected subcutaneously (sc) or intracutaneously (ic) into various experimental animals it causes haemorrhage and necrosis (Munoz, 1971). A sensitive method for detecting HLT activity is by injecting it sc or ic into suckling mice and scoring the haemorrhagic reaction after $24-48 \mathrm{~h}$ (Katsampes $e t$ al., 1942; Kurokawa et al., 1969; Cowell et al., 1979; Livey and Wardlaw, 1984). Most studies on HLT have involved the use of crude cell extracts in which the activities attributed to HLT have been based on the difference in activity before and after heating at $56 \mathrm{C}$. However, the purified preparations of Onoue et al. (1963) and Nakase et al. (1969) retained their dermonecrotising and lethal activities.

The mechanisms of pathogenesis of human pertussis are still obscure and the role of HLT has not been defined (Pittman, 1979). However, the marked effects seen in laboratory animals after injection of HLT strongly suggest that it has a significant part in the disease process (Munoz, 1971; Olson, 1975; Wardlaw and Parton, 1983). Recently, it was shown that prednisolone, given orally or ip before chal-

Received 17 Jun. 1985; accepted 30 Jul. 1985. lenge, would protect mice against the lethal effects of HLT (Parton, 1985). Glucocorticoids such as prednisolone have been reported to be beneficial in the treatment of children with severe pertussis, by reducing the frequency and severity of the coughing spasms and the duration of the illness (Dayal et al., 1969; Zoumboulakis et al., 1973; Barrie, 1982; Dianese, 1982). These findings raise the possibility that the beneficial effects of corticosteroids are due to their counteracting some action of HLT in the child (Parton, 1985).

In the present investigations, HLT was assayed by the haemorrhagic response after sc injection in weaned mice. The ability of a steroidal and a nonsteroidal anti-inflammatory agent to inhibit this reaction is reported.

\section{Materials and methods}

\section{Heat-labile toxin}

A crude cell extract of $B$. pertussis served as a convenient source of HLT. The extract was prepared from B. pertussis strain 18334 grown in modified Hornibrook medium (Wardlaw et al., 1976) for $48 \mathrm{~h}$ at $37^{\circ} \mathrm{C}$, as described previously (Idigbe et al., 1981). Cultures were harvested by centrifugation at $10000 \mathrm{~g}$ for $30 \mathrm{~min}$ at $4 . \mathrm{C}$. Packed cells were resuspended in saline $(\mathrm{NaCl} 0.85 \%$ $\mathrm{w} / \mathrm{v}$ ), and, after freezing, were disrupted by three passages through an X-press (Life Sciences Laboratories, Sarum Road, Luton). After thawing, the suspension was centrifuged at $100000 \mathrm{~g}$ for $30 \mathrm{~min}$ at $4^{\circ} \mathrm{C}$. The supernate of the 
cell lysate (cell extract) was distributed in small amounts and stored at $-20^{\circ} \mathrm{C}$. For use, it was thawed and diluted in sterile saline. Protein estimation on the cell extract was done by the method of Herbert et al. (1971) with bovine serum albumin as a standard.

\section{Skin reactions}

These were assessed in 3-4-week-old male HaM/ICR mice (Charles River UK Ltd, Manston Road, Margate, Kent CT9 4LT) except where stated. After ether anaesthesia, groups of five or ten mice were given injections of $0.05 \mathrm{ml}$ of a suitable dilution of the crude extract sc in the dorsal region. After $24 \mathrm{~h}$ the animals were killed with $\mathrm{CO}_{2}$ and the diameters of the haemorrhagic reactions within the skin were measured. In the case of large irregularlyshaped reactions, the mean of the largest and smallest dimensions was determined.

\section{Anti-inflammatory agents}

Prednisolone-21-sodium succinate was obtained from Sigma. Sodium meclofenamate monohydrate was a gift from Parke, Davis and Co. Ltd, Usk Road, Pontypool, Gwent. For injection, both were dissolved in sterile saline.

\section{Statistical analysis}

The mean diameters of skin reactions in test and control groups were compared by Student's $t$ test. Diameters of reactions were shown to be normally distributed by Rankit analysis (Bliss, 1967).

\section{Results}

\section{Effect of age of mice on skin reactions to HLT}

Although suckling mice ( $<3$ weeks old) have been used previously for detecting HLT activity, the possibility of using random groups of weaned ( $>3$ week-old) mice was investigated. The age of the animals had a marked effect on the haemorrhagic response to the cell extract (fig. 1). Groups of 10 male or female mice of different age ranges were given sc injections of cell extract containing $1 \cdot 2 \mu \mathrm{g}$ of protein and, the diameters of the haemorrhagic reactions within the skin were measured after $24 \mathrm{~h}$. Mice 3-5 weeks old showed the largest reaction, $c$. $17-20 \mathrm{~mm}$ in diameter. Older mice were less responsive; little if any reaction was seen in animals older than 7 weeks. There was no significant difference in the responsiveness of male and female mice. When cell extracts were injected ic into the shaved backs of mice, reactions in young and old mice were of similar diameter and severity to those seen after sc injection (data not shown). In all subsequent experiments, HLT samples were injected sc into male mice, 3-4 weeks old.

The heat lability of the toxic activity was demonstrated by heating the cell extract to $56^{\circ} \mathrm{C}$ for 20 min. No haemorrhagic effect was seen with such heated samples, even with a dose 400 -fold higher than that used above.

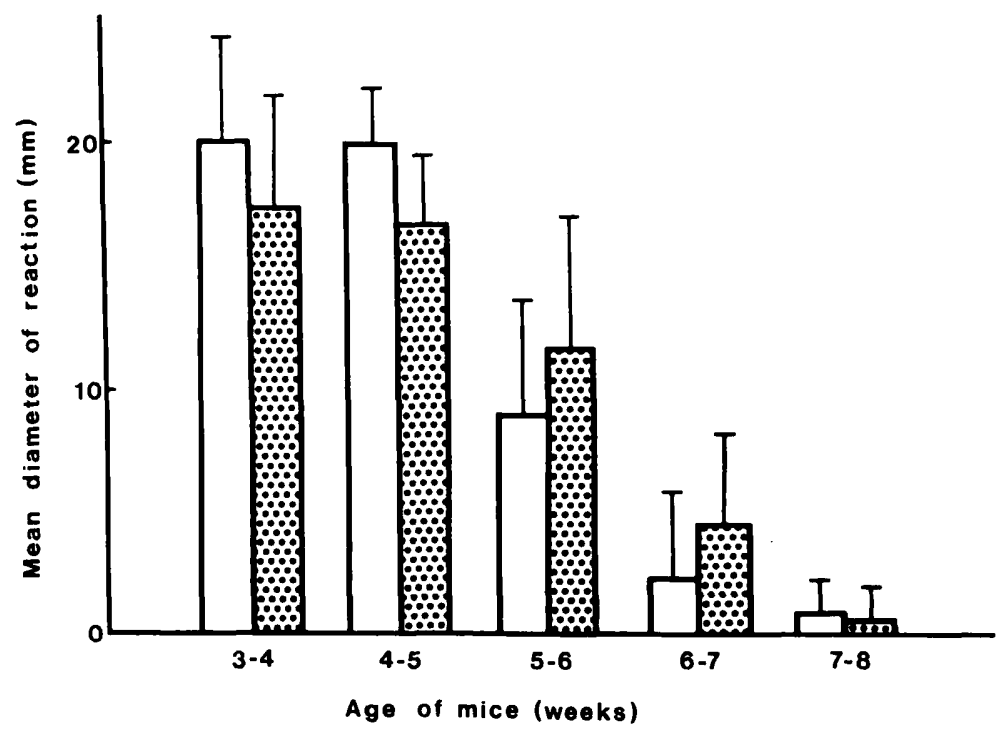

Fig. 1. Effects of age and sex of mice on the haemorrhagic reaction to $B$. pertussis cell-extract (containing $1 \cdot 2 \mu \mathrm{g}$ of protein) injected sc. The unshaded and shaded areas are the results for groups of 10 female and male mice respectively. The bars represent 1 SD. 


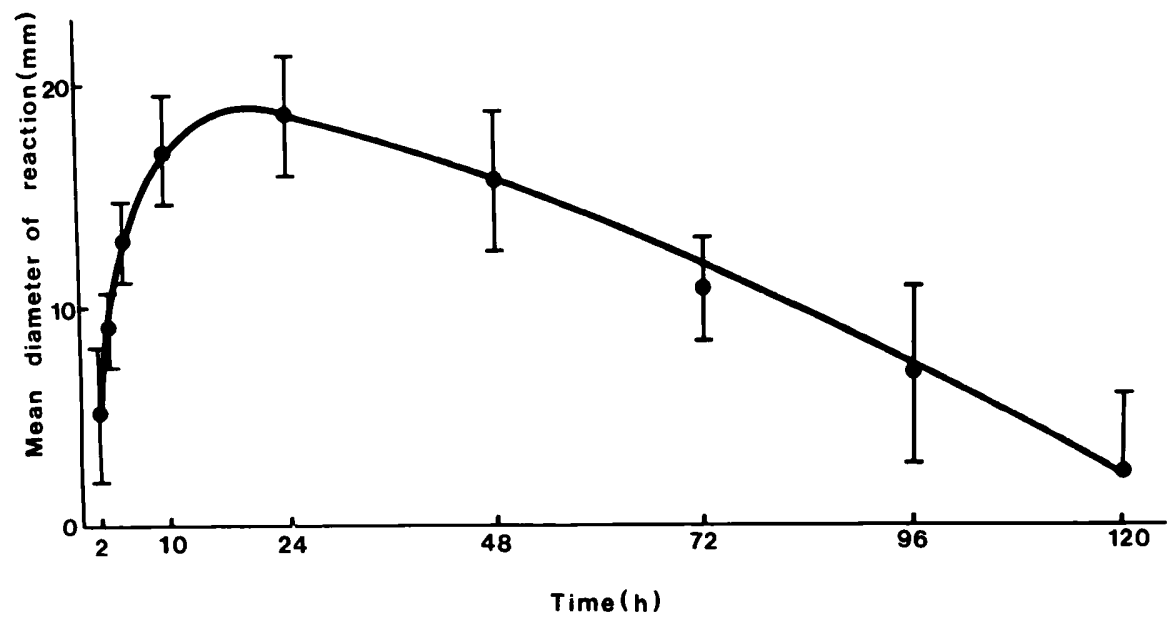

Fig. 2. Time course of the haemorrhagic response to $B$. pertussis cell-extract injected sc. Groups of five mice were used and each mouse received cell-extract containing $1.2 \mu \mathrm{g}$ of protein. The bars represent $\pm 1 \mathrm{SD}$.

\section{Time course of skin reactions}

Fig. 2 shows the time course of the response to the cell extract injected sc. Numerous petechiae were visible at the site of injection within $2 \mathrm{~h}$ of challenge. Thereafter, there was a rapid increase in the diameter and severity of the reaction, with the most pronounced reaction, a dark haemorrhagic zone with some oedema, at c. $24 \mathrm{~h}$. By day 5 after challenge the reactions had largely disappeared.
Inhibition of skin reactions by prednisolone or meclofenamate

A high dose of prednisolone sodium succinate ( $3 \mathrm{mg} / \mathrm{mouse}$ ) given ip reduced significantly the haemorrhagic response to HLT; the degree of reduction depended on the time of administration of the drug (fig. 3). The greatest inhibition occurred when the prednisolone was given $1 \mathrm{~h}$ before, or at the same time as, the HLT challenge. When given

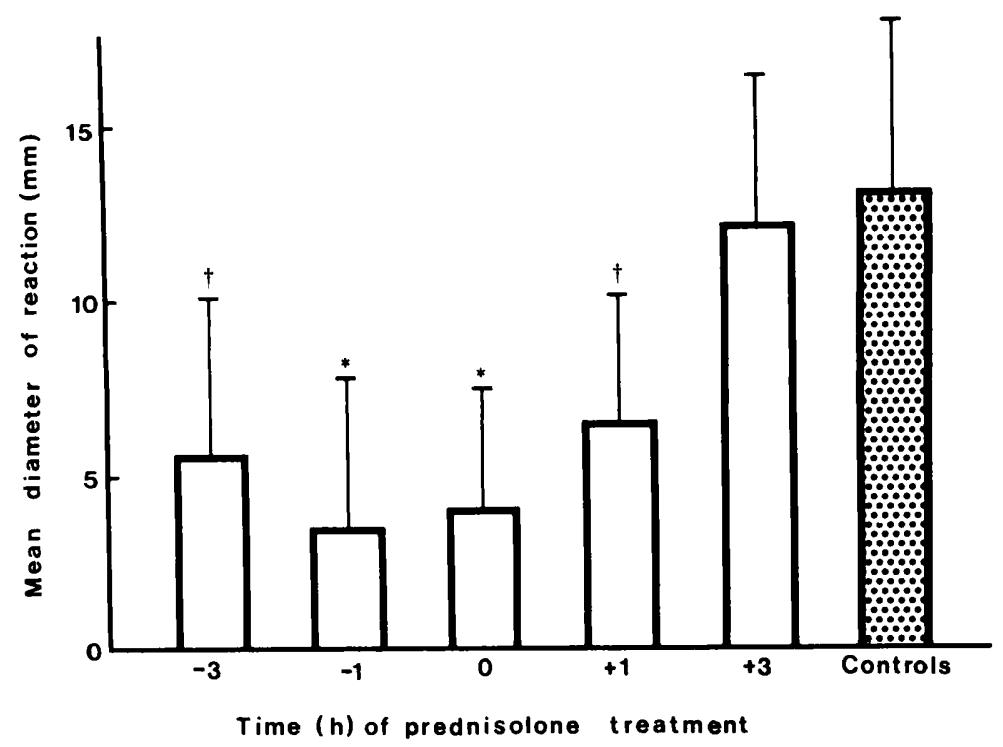

Fig. 3. Effect of prednisolone sodium succinate on the haemorrhagic reactions due to HLT. The drug ( $3 \mathrm{mg} / \mathrm{mouse})$ was given ip before or after or at the time of challenge. Groups of 10 mice were given cell-extract containing $0.6 \mu \mathrm{g}$ of protein/mouse by sc injection at time 0 . By Student's $t$ test for difference between test and control groups: ${ }^{*}=$ highly significant $(p \leqslant 0.01) ; \dagger=\operatorname{significant}(p \leqslant 0.05)$. The bars represent $1 \mathrm{SD}$. 
$1 \mathrm{~h}$ after challenge, there was still a significant reduction in the eventual response; but when given $3 \mathrm{~h}$ afterwards, no significant protection was seen.

A non-steroidal anti-inflammatory agent, sodium meclofenamate, also inhibited the haemorrhagic response to HLT. The effects of prednisolone and meclofenamate were compared by injecting graded doses of the drugs ip into groups of mice $1 \mathrm{~h}$ before challenge with HLT. Table I shows the diameters of the skin reactions in these mice compared with controls. In both cases, large amounts of the drug ( $\geqslant 1 \mathrm{mg} / \mathrm{mouse}$ or $c .70 \mathrm{mg} / \mathrm{kg}$ of body weight) were required to give a significant reduction in the diameters of the skin reactions. Prednisolone was also effective at a similar dose level when administered orally, by incorporating the drug in the drinking water for 2 days before challenge. A dose of prednisolone sodium succinate $1.5 \mathrm{mg} / \mathrm{mouse} /$ day gave a highly significant reduction in skin response $(P<0.01)$ whereas with 0.75 $\mathrm{mg} / \mathrm{mouse} /$ day, there was no significant reduction $(P>0.05)$.

Prednisolone and meclofenamate were more effective when mixed with HLT before injection sc (table II). Presumably, much higher local concentrations of the drugs were achieved. A $250-\mu \mathrm{g}$ dose of prednisolone sodium succinate gave a significant reduction in the diameter of the reaction, and higher doses inhibited the reaction completely. Sodium meclofenamate was even more active. The reactions were completely inhibited by $25 \mu \mathrm{g}$ of the drug; and at $6.25 \mu \mathrm{g}$, the lowest dose tested, there was a highly significant reduction in skin reaction.

Table I. Effect of ip prednisolone or meclofenamate on the haemorrhagic reactions to $B$. pertussis cell extract injected sc into groups of five mice*

\begin{tabular}{|c|c|c|}
\hline Treatment & $\begin{array}{c}\text { Drug dose } \\
\text { (mg/mouse) }\end{array}$ & $\begin{array}{c}\text { Mean diameter }(\mathrm{mm}) \\
\text { of skin reaction } \pm \mathrm{SD} \\
\text { (and significance } \dagger \text { ) }\end{array}$ \\
\hline $\begin{array}{l}\text { Prednisolone } \\
\text { sodium succinate }\end{array}$ & $\begin{array}{l}3 \\
1 \cdot 5 \\
0.75\end{array}$ & $\begin{array}{c}7.8 \pm 5.4(\mathrm{~S}) \\
10.0 \pm 4 \cdot 1 \text { (NS) } \\
13 \cdot 6 \pm 3 \cdot 6(\mathrm{NS})\end{array}$ \\
\hline $\begin{array}{l}\text { Sodium } \\
\text { meclofenamate } \\
\text { Saline }\end{array}$ & $\begin{array}{l}1 \\
0.5 \\
0 \cdot 25 \\
\text { (control } \\
\text { group) }\end{array}$ & $\begin{array}{l}9 \cdot 8 \pm 3 \cdot 2(\mathrm{~S}) \\
12 \cdot 6 \pm 3 \cdot 9(\mathrm{NS}) \\
13 \cdot 2 \pm 4 \cdot 5(\mathrm{NS}) \\
15 \cdot 0 \pm 3 \cdot 1\end{array}$ \\
\hline
\end{tabular}

* Each mouse received cell-extract containing $0.6 \mu \mathrm{g}$ of protein $1 \mathrm{~h}$ after injection of drug or saline.

$\dagger$ By Student's $t$ test for difference between test and control groups: $H S=$ highly significant $(p \leqslant 0.01) ; S=$ significant $(p ; \leq 0.05) ; N S=$ not significant $(p>0.05)$.
Table II. Effect of prednisolone or meclofenamate on the haemorrhagic reactions to HLT, when the drug was mixed with cell extract and injected sc into groups of five mice*

\begin{tabular}{cl|l}
\hline \multicolumn{1}{c|}{ Treatment } & $\begin{array}{c}\text { Drug dose } \\
(\mu \mathrm{g} / \mathrm{mouse})\end{array}$ & $\begin{array}{c}\text { Mean diameter (mm) } \\
\text { of skin reactions } \pm \mathrm{SD} \\
\text { (and significance })\end{array}$ \\
\hline Prednisolone & 500 & no reactions \\
& 250 & $12 \cdot 4 \pm 2 \cdot 1$ (S) \\
sodium succinate & 125 & $14 \cdot 8 \pm 2 \cdot 6(\mathrm{NS})$ \\
& $62 \cdot 5$ & $16 \cdot 8 \pm 2 \cdot 2$ (NS) \\
Sodium & 25 & no reactions \\
meclofenamate & $12 \cdot 5$ & $5 \cdot 8 \pm 1 \cdot 8(\mathrm{HS})$ \\
& $6 \cdot 25$ & $8 \cdot 0 \pm 2 \cdot 0$ (HS) \\
Saline & (control & $16 \cdot 6 \pm 2 \cdot 2$ \\
& group) & \\
\hline
\end{tabular}

\footnotetext{
* Each injection mixture contained $0.6 \mu \mathrm{g}$ of cell-extract protein.

† See footnote to table I.
}

\section{Discussion}

The mechanism of action of HLT is unknown and there is no in-vitro assay for the toxin. The haemorrhagic response to $B$. pertussis cell extracts injected sc into 3-4-week-old mice, as described here, provided a convenient way of detecting HLT activity. Previous workers have used suckling mice (Katsampes et al., 1942; Kurokawa et al., 1969; Cowell et al., 1979; Livey and Wardlaw, 1984) but it is not clear from the literature that mice become less responsive with age. Violle (1950) reported that mice were unresponsive to HLT but the age of the animals was not specified. The reason for this loss of sensitivity to HLT as the mice mature is not known, but preliminary experiments have shown that the same phenomenon occurs also in Wistar (albino) and DA (agouti) rats of different ages (unpublished observations). It is interesting to note the parallel between the HLT responsiveness of these animals and the known age-related severity of pertussis in children (Miller and Fletcher, 1976). With another toxic product of $B$. pertussis (variously called pertussigen, pertussis toxin, histamine-sensitising factor, lymphocytosis-promoting factor, etc.) generally regarded as having a central role in the pathogenesis of whooping cough, mice become more responsive to its histamine-sensitising properties as they mature (Munoz and Bergman, 1968).

The anti-inflammatory agents prednisolone and meclofenamate inhibited the haemorrhagic effect produced by HLT in mouse skin. In a previous report (Parton, 1985), prednisolone was shown to 
protect mice against the lethal effect of HLT. In both cases, prednisolone was most effective if given just before, or at the same time as, the HLT challenge. When drug treatment was delayed until $3 \mathrm{~h}$ after challenge, no significant protection was given. In the case of the skin response, the reactions would have started to appear by this time. This suggests that some chain of events had been started by HLT and could not be reversed by these drugs.

Both prednisolone and meclofenamate prevent the generation of arachidonic acid metabolites which are potential mediators of inflammation (Nickander et al, 1979). Corticosteroids are thought to inhibit the first step in this reaction, the release of arachidonic acid from membrane phospholipids in target cells. Non-steroidal anti-inflammatory agents such as meclofenamate are thought to act primarily to inhibit prostaglandin synthetase, but, like corticosteroids, they may have other actions (Hart and Huskisson, 1984). Thus, it is possible that one or more of the arachidonic acid metabolites plays an important role in the lethal and skinhaemorrhagic effects of HLT in the mouse. These studies do not, however, shed any light on the primary sites of HLT activity because many nonspecific stimuli can promote the arachidonic acid cascade.

Nakase and Endoh (in press) described the effects of purified HLT on surgically-exposed peripheral

\section{REFERENCES}

Barrie H 1962 Treatment of whooping cough. Lancet 2:830-831. Bliss C I 1967 Statistics in biology, vol. I. McGraw-Hill, New York

Broomhall J, Herxheimer A 1984 Treatment of whooping cough: the facts. Archives of Disease in Childhood 59:185-187.

Cowell J L, Hewlett E L, Manclark C R 1979 Intracellular localization of the dermonecrotic toxin of Bordetella pertussis. Infection and Immunity 25:896-901.

Dayal R S, Atal P R, Kumar Y 1969 A comparative study of different culture techniques and therapeutic efficacy of newer antibiotics in pertussis. Indian Journal of Medical Sciences 23:421-427.

Dianese G 1982 Treatment of whooping cough: Lancet 2:1224.

Hart F D, Huskisson E C 1984 Non-steroidal anti-inflammatory drugs. Current status and rational therapeutic use. Drugs 27:232-255.

Herbert D, Phipps P J, Strange R E 1971 Chemical analysis of microbial cells. In: Norris J R, Ribbons D W (eds) Methods in microbiology, vol. 5B. Academic Press, London, pp 209 344.

Idigbe E O, Parton R, Wardlaw A C 1981 Rapidity of antigenic modulation of Bordetella pertussis in modified Hornibrook medium. Journal of Medical Microbiology 14:409-418.

Katsampes C P, Brooks A M, Bradford W L 1942 Toxicity of washings from Hemophilus pertussis for mice. Proceedings of the Society for Experimental Biology and Medicine 49:615-618. blood vessels of guinea-pigs and suckling mice. Within $15 \mathrm{~min}$, HLT had induced a sustained vasoconstriction which eventually led to haemorrhage and oedema. It is interesting to note that certain prostaglandin, thromboxane and leukotriene derivatives of arachidonic acid are potent vasoconstrictors (Nickander et al., 1979; Samuelsson, 1983). It may be possible to identify the important mediators by examining the effects of other, more specific inhibitors or mimetics of these agents in the mouse model described here.

In a review on the treatment of whooping cough, Broomhall and Herxheimer (1984) suggested that carefully designed clinical trials should be set up in which several forms of treatment, including corticosteroids, could be assessed. If HLT has an important role in the pathogenesis of pertussis, as seems possible (Munoz, 1971; Olson, 1975; Wardlaw and Parton, 1983), the present work suggests that non-steroidal anti-inflammatory agents also may be worthy of investigation. Further studies on the effects of a range of anti-inflammatory agents on the various pathophysiological activities of $B$. pertussis toxins in mice could help in the selection of the most likely candidates.

I thank Professor A. C. Wardlaw for his advice and encouragement, Dr B. Furman for suggesting the use of meclofenamate and Mrs Elizabeth Berry for skilled technical assistance.

Kurokawa M, Ishida S, Asakawa S 1969 Attempts at analysis of toxicity of pertussis vaccine. II. Quantitative determination of the heat-labile toxin by skin reaction. Japanese Journal of Medical Science and Biology 22:293-307.

Livey I, Wardlaw A C 1984 Production and properties of Bordetella pertussis heat-labile toxin. Journal of Medical Microbiology 17:91-103.

Miller C L, Fletcher W B 1976 Severity of notified whooping cough. British Medical Journal 1:117-119.

Munoz J 1971 Protein toxins from Bordetella pertussis. In: Kadis S, Montie T C, Ajl S J (eds) Microbial toxins, vol Ila, Bacterial protein toxins. Academic Press, New York, pp 271-300.

Munoz J, Bergman R K 1968 Histamine-sensitizing factors from microbial agents, with special reference to Bordetella pertussis. Bacteriological Reviews 32:103-126.

Nakase Y, Endoh M Bordetella heat-labile toxin: further purification, characterization and mode of action. Proceedings of the Fourth International Symposium on Pertussis, Geneva, 1984. (in press).

Nakase Y, Takatsu K, Tateishi M, Sekiya K, Kasuga T 1969 Heat-labile toxin of Bordetella pertussis purified by preparative acrylamide gel electophoresis. Japanese Journal of Microbiology 13:359-366.

Nickander R, McMahon F G, Ridolfo A S 1979 Nonsteroidal anti-inflammatory agents. Annual Review of Pharmacology and Toxicology 19:469-490.

Olson L C 1975 Pertussis. Medicine (Baltimore) 54: 427-469.

Onoue K, Kitagawa M, Yamamura Y 1963 Chemical studies on 
cellular components of Bordetella pertussis. III. Isolation of highly potent toxin from Bordetella pertussis. Journal of Bacteriology 86:648-655.

Parton R 1985 Effect of prednisolone on the toxicity of Bordetella pertussis for mice. Journal of Medical Microbiology 19:391-400.

Pittman M 1979 Pertussis toxin: the cause of the harmful effects and prolonged immunity of whooping cough. A hypothesis. Reviews of Infectious Diseases 1:401-412.

Samuelsson B 1983 Leukotrienes: mediators of immediate hypersensitivity reactions and inflammation. Science 220:568-575.
Violle H 1950 Sur le pouvoir dermo-nécrotique du bacille de la coqueluche. Bulletin Academiea Nationale de Médécine (Paris) 134:518-521.

Wardlaw A C, Parton R 1983 Bordetella pertussis toxins. Pharmacology and Therapeutics 19:1-53.

Wardlaw A C, Parton R, Hooker M J 1976 Loss of protective antigen, histamine-sensitising factor and envelope polypeptides in cultural variants of Bordetella pertussis. Journal of Medical Microbiology 9:89-100.

Zoumboulakis D, Anagnostakis D, Albanis V, Matsaniotis N 1973. Steroids in treatment of pertussis: a controlled clinical trial. Archives of Disease in Childhood 48:51-54. 